\title{
Lower Palaeozoic stratigraphy of southern Peary Land, eastern North Greenland
}

\section{John S. Peel and Robert L. Christie}

The geology of the area around $\mathbf{J} \phi$ rgen Brønlund Fjord has previously been described by Koch (1923) and Troelsen (1949, 1956), while Jepsen (1971) recently discussed the late Precambrian - early Cambrian sequence. The two month field season in 1974 was designed to complement this work by establishing a reference profile through the Lower Palaeozoic sequence exposed in the valley of Børglum Elv to the north of its outflow into Jørgen Brønlund Fjord (fig. 5). Substantial lithological and palaeontological collections were made from approximately $2500 \mathrm{~m}$ of strata examined in nine stratigraphic sections.

The lowest rocks examined in detail are clastic sediments of the Buen Formation of Early Cambrian age which are overlain by mainly carbonates of Early Cambrian to Early or Middle Silurian ages. These are succeeded by probable Middle Silurian

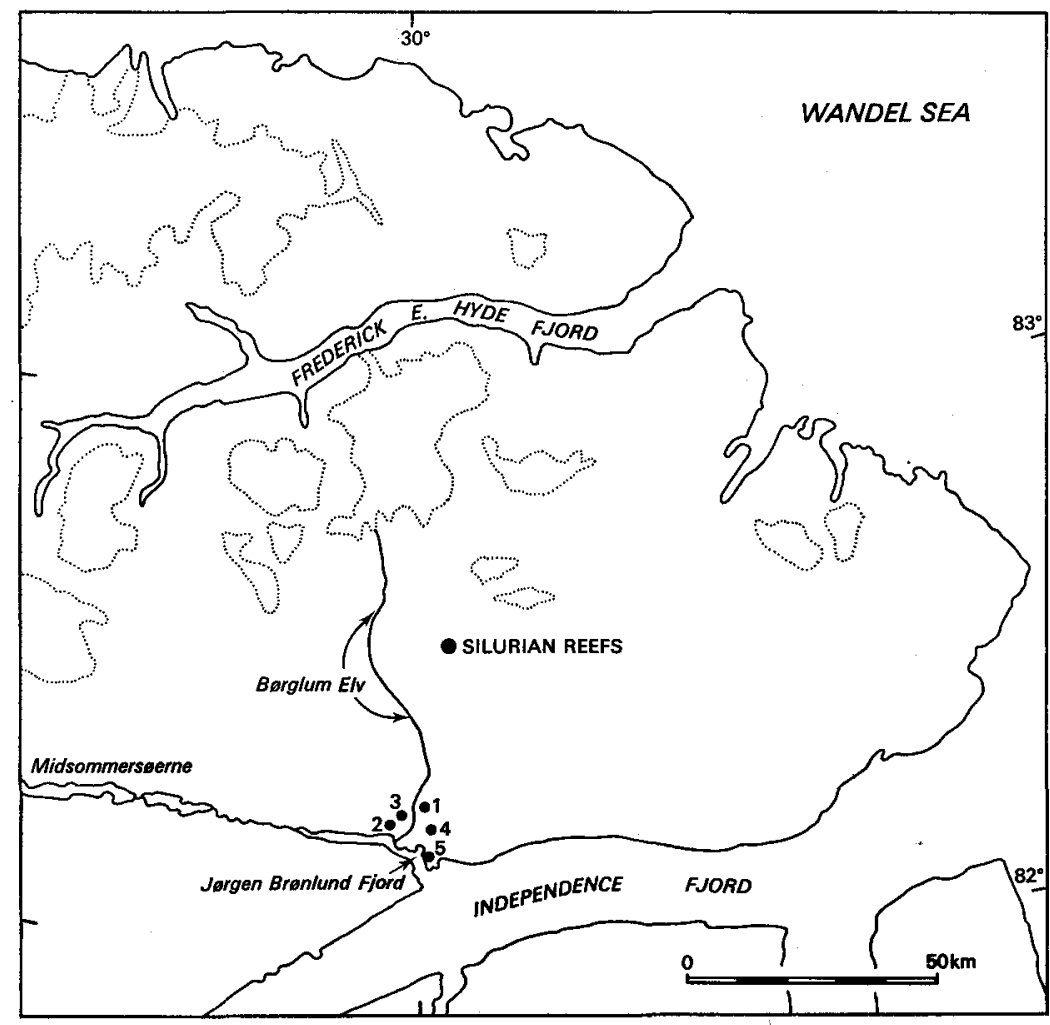

Fig. 5. Peary Land showing the location of the Børglum Elv area. 1-4, localities of collections made by J. C. Troelsen discussed by Yochelson \& Peel (this report). 1, collection 11; 2, collections 13a, b; 3, collections 14a, b; 4, collection 15. 5, Kap Moltke base station. 


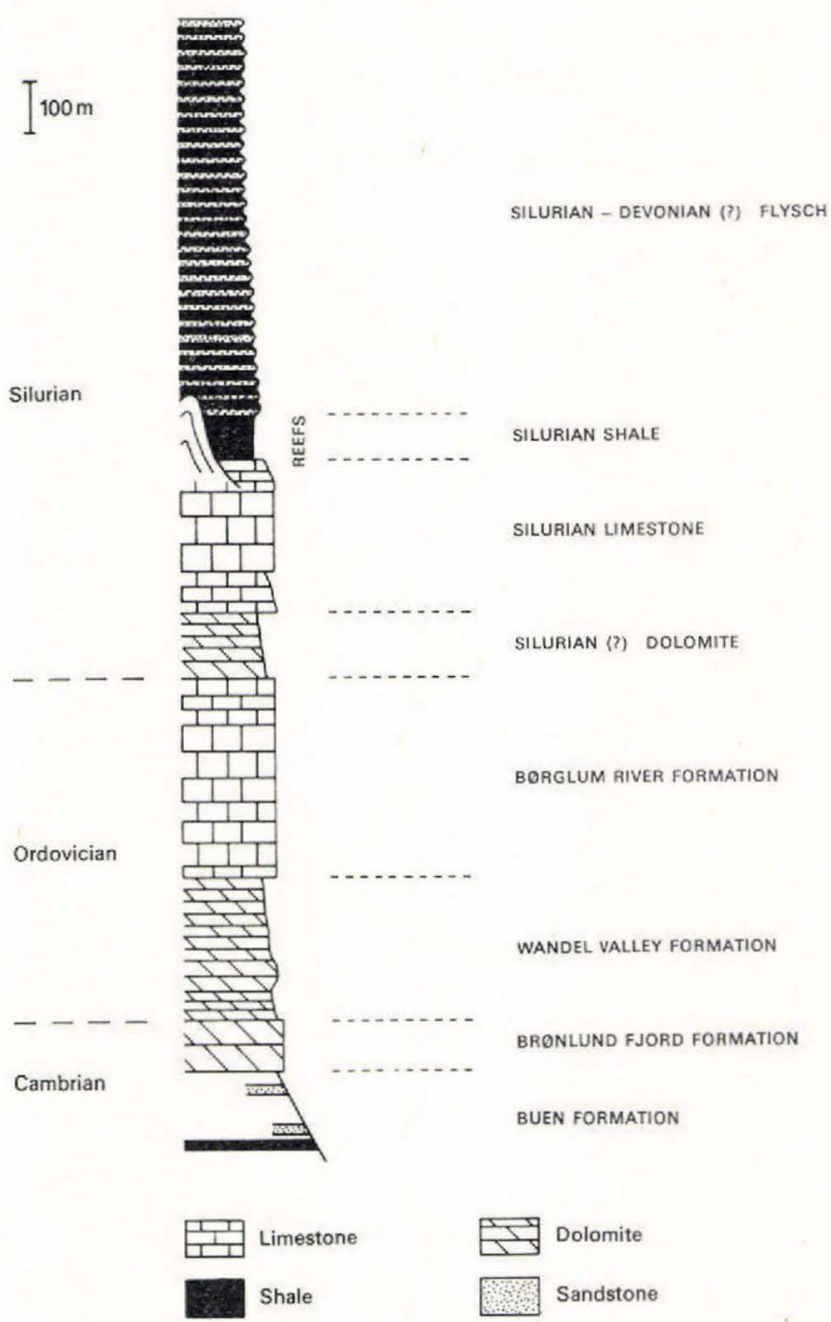

Fig. 6. Simplified geological section in the Bø̈rglum Elv area, southern Peary Land.

graptolitic shales and by a late Silurian and younger(?) flysch sequence. Reefs occur at the top of the carbonate development (fig. 6). The strata have a slight northward dip so that succêssively younger beds appear to the north.

\section{Buen Formation}

Only the uppermost $160 \mathrm{~m}$ of this formation, originally defined by Jepsen (1971), were examined. Dark, fissile shales at Brilles $\varnothing$ yielded a large collection of olenellid trilobites, mainly Holmia hyperborea Poulsen, 1974 (originally described from this 
locality), and hyolithids indicative of an Early Cambrian age. Succeeding thinly bedded turbiditic sandstones and shales are not well exposed in the measured sections but contain poorly preserved hyolithids.

\section{Brønlund Fjord Formation}

The Brønlund Fjord Formation (Brønlund Fjord Dolomite of Troelsen, 1949) forms conspicuous cliffs along the northern side of Jørgen Brønlund Fjord and Independence Fjord. A number of variously coloured lithological types are present within the $100 \mathrm{~m}$ thick dolomite unit, including laminated, massive and brecciated horizons. The poorly exposed basal member consists of about $3 \mathrm{~m}$ of grey dolomite with a rich Early Cambrian fauna of hyolithids, inarticulate brachiopods, and olenellid trilobite fragments. The fauna is seemingly the same as that noted by Peel et al. (1974) from an equivalent stratigraphic position at Midsommersøerne, $100 \mathrm{~km}$ to the west. The remainder of the formation has not yielded fossils, other than poorly preserved stromatolites at the top.

\section{Wandel Valley Formation}

The Brønlund Fjord Formation is conformably overlain by about $320 \mathrm{~m}$ of thinly bedded to medium bedded dolomite of the Wandel Valley Formation (Wandel Valley Limestone of Troelsen, 1949). Dark dolomites, making up the middle member and forming thin intercalations within the pale weathering lower member, contain abundant silicified gastropods and cephalopods. The presence of Ceratopea ankylosa and $C$. unguis indicates a Late Canadian (Early Ordovician) age (Yochelsen \& Peel, this report). The upper member, which accounts for almost two thirds of the formation thickness, consists of poorly fossiliferous dolomite similar to that of the lower member.

\section{Børglum River Formation}

The Børglum River Formation (Børglum River Limestone of Troelsen, 1949) is composed of about $430 \mathrm{~m}$ of yellow-grey weathering, often conspicuously mottled, limestones which contrast markedly with the underlying dolomite of the Wandel Valley Formation. The change from dolomite to limestone is abrupt, but inconspicuous, due to the general similarity of the basal limestone beds and the dolomite. Most of the B $\varnothing$ rglum River Formation is thick bedded and competent but upper beds tend to be less competent. Fossils, characteristically including large macluritid gastropods and tabulate corals, are present throughout the formation. Richly fossiliferous beds in the upper part yielded Lobocorallium, Kochoceras, Calapoecia, and favositid and halysitid corals indicative of a Late Ordovician age.

Collections made by J. C. Troelsen from the Børglum River Formation between 1947 and 1949, which Peel et al. (1974) failed to locate, have subsequently been found in the care of Dr. J. W. Cowie, University of Bristol. Cursory examination suggests that they are comparable to collections obtained in 1974. 


\section{Silurian (?) dolomite}

About $150 \mathrm{~m}$ of medium bedded dolomite conformably overlies the B $\emptyset \mathrm{rglum}$ River Formation. A lower member is composed of pale grey dolomite while succeeding strata are mainly dark grey weathering. Poorly preserved brachiopods and corals occur at several horizons.

\section{Silurian limestone}

A sequence of variable limestones, $320 \mathrm{~m}$ in thickness, overlies the Silurian(?) dolomite. The limestones weather light grey, dark grey and yellowish grey and are often richly fossiliferous. Mottled beds are prominent and a variable degree of silicification is present at certain horizons. Large pentamerid brachiopods are conspicuous at two levels in the lower part of the unit. Succeeding strata contain abundant favositid and halysitid corals and leperditiid ostracodes. A thick bedded limestone member is prominent in the upper part of the unit and outcrops over large areas of upland adjacent to Børglum Elv. The uppermost $35 \mathrm{~m}$ of strata are medium bedded, rubbly limestones with Strophonella, Amplexoides, Favosites, trilobites and gastropods.

\section{Silurian reefs}

Reefs are an important element in the Silurian of Greenland and form a conspicuous belt across much of North Greenland (Dawes, 1971). Two reefs lying approximately $15 \mathrm{~km}$ east of Børglum Elv and $40 \mathrm{~km}$ north of Kap Harald Molkte were examined (fig. 5). One of the reefs forms a crescent nearly $2 \mathrm{~km}$ long while the second, smaller structure lies a few hundred metres away to the north. Hills of light weathering carbonate to the south of these two structures may represent a continuation of the bioherm. The reefs occur at the top of the Cambrian to Middle Silurian carbonate sequence but they appear to occupy stratigraphical positions well into the overlying clastics, with the younger shale and flysch successively lapping onto and over the reefs. The biohermal rocks are mainly pale grey, bioclastic limestones with abundant fossils. Stromatoporoids and corals are most common but pentamerid brachiopods, trilobites and gastropods are also well represented.

\section{Silurian shale}

The Cambrian to Silurian carbonate sequence is followed by a recessive unit comprising about $100 \mathrm{~m}$ of soft dark shales and fine-grained, grey siltstones. The presence of a single poor cyrtograptid, associated with large Monograptus spp. and an orthocone nautiloid, possibly suggests a Wenlock age, although cyrtograptids are known to occur in the Late Llandovery of the North American arctic.

\section{Silurian and Devonian (?) flysch}

A thick sequence of interbedded, impure turbiditic sandstones, siltstones and shales conformably overlies the Silurian shale. Alternating resistant and less resistant beds 
produce distinctive terraced hills throughout much of the northern part of the Børglum Elv area. A section of some $800 \mathrm{~m}$ thickness was briefly examined and younger beds probably occur to the north. The highest observed beds consist of a few tens of metres of conglomerate exposed near the ice cap that forms the source of B $\varnothing$ rglum Elv. Large Monograptus spp., associated with eurypterid remains, in sandstones near the base of the sequence indicate a Late (?) Silurian age. However, the flysch sequence of southern Peary Land probably extends into the Devonian since Early Devonian graptolites have been obtained from an equivalent sequence in western North Greenland (Berry et al., 1974). The name Kjoveslette Sandstones has been applied to blocks of similar lithology occurring as loose slabs in marine post-glacial deposits at Kjovesletten, eastern Peary Land (Peel et al., 1974).

\section{Acknowledgements}

Transport to the area was by a C-54 of the Royal Danish Air Force attached to Iscentralen, Narssarssuaq. Helicopter assistance in laying out bases at the beginning of the season was kindly provided by the Danish military ('Operation Brilliant Ice'). Count Eigil Knuth's personnel at Kap Moltke provided generous hospitality on arrival and departure. The party was lifted out in early August by a military C-54 and by a DC-3 on charter from Bradley Air Services Ltd.

\section{References}

Berry, W. B. N., Boucot, A. J., Dawes, P. R. \& Peel, J. S. 1974: Late Silurian and early Devonian graptolites from North Greenland. Rapp. Gronlands geol. Unders. 65, 11-13.

Dawes, P. R. 1971: The North Greenland fold belt and environs. Bull. geol. Soc. Denmark 20, 197-239.

Jepsen, H. F. 1971: The Precambrian, Eocambrian and early Palaeozoic stratigraphy of the J $\phi$ rgen Brønlund Fjord area, Peary Land, North Greenland. Bull. Grønlands geol. Unders. 96 (also Meddr Gronland 192,2) 42 pp.

Koch, L. 1923: Preliminary report upon the geology of Peary Land, Arctic Greenland. Am. J. Sci. 5th Ser. 5, 189-199.

Peel, J. S., Dawes, P. R. \& Troelsen, J. C. 1974: Notes on some Lower Palaeozoic to Tertiary faunas from eastern North Greenland. Rapp. Grønlands geol. Unders. 65, 18-23.

Troelsen, J. C. 1949: Contributions to the geology of the area round Jørgen Brønlunds Fjord, Peary Land, North Greenland. Meddr Grønland 149, 2, 29 pp.

Troelsen, J. C. 1956: The Cambrian of North Greenland and Ellesmere Island. 20 Congr. geol. int. Mexico. 3(1), 71-90.

R.L.C.,

Institute of Sedimentary and Petroleum Geology, 3303, 33rd Street NW, Calgary, Alberta T2L 2A7, Canada. 